\title{
Whole-Farm Phosphorus Balance on Western Dairy Farms ${ }^{1}$
}

\author{
R. A. Spears, ${ }^{\star}$ A. J. Young, ${ }^{\star}$ and R. A. Kohn† \\ *Animal, Dairy, and Veterinary Sciences Department, \\ 4815 Old Main Hill, Utah State University, Logan 84322-4815 \\ †Department of Animal and Avian Sciences, \\ Animal Science Center, \\ University of Maryland, College Park 20742-2311
}

\section{ABSTRACT}

Environmental concerns have focused attention on animal agriculture and its contribution to $\mathrm{P}$ accumulation in soils and runoff to surface waters. Monitoring $P$ inputs and outputs on farms is a means of calculating the potential $\mathrm{P}$ build-up in farm soils. The objective of this study was to determine whole-farm $\mathrm{P}$ balance and the relative importance of the farm components (herd, manure storage, cropping systems) that contribute to it in dairies of the western United States. Whole-farm balances were computed for 41 commercial dairies in Utah and Idaho using the Maryland Nutrient Balancer. The average whole-farm $\mathrm{P}$ balance in the study was 6.6 tonne/yr with an average herd size of 466 cows. Imported feed made up $85.4 \%$ of the total $\mathrm{P}$ inputs and exported animal products (milk and meat), and manure and compost made up 53.1 and $45.9 \%$, respectively, of the total P outputs. Farms were divided into those that grew crops and those that did not. Whole-farm balance ( $\mathrm{kg}$ of $\mathrm{P}$ balance per animal) for farms that grew crops had more unaccounted for $\mathrm{P}$ (difference between $\mathrm{P}$ inputs and output) than farms that grew no crops. They also had more imported fertilizer and less imported feed and exported manure and compost. Multiple regression analysis of the relative effects of herd management, manure storage, and cropping system on whole-farm balance per product found that herd $\mathrm{P}$ utilization efficiency was the most important factor in determining whole-farm $\mathrm{P}$ balance on farms where crops were grown. Crop uptake of available $\mathrm{P}$ was the only other subsystem important for these farms. Increased conversion of feed $\mathrm{P}$ to $\mathrm{P}$ in product is an important way to decrease whole-farm $\mathrm{P}$ balance.

(Key words: phosphorus balance, commercial dairies, western United States)

Received June 18, 2002.

Accepted September 9, 2002.

Corresponding author: A. J. Young; e-mail: alleny@ext.usu.edu.

${ }^{1}$ This research was supported by SARE grant no. SW99-024, and by the Utah Agricultural Experiment Station, Utah State University, Logan, UT 84322-4810. Approved as paper no. 7451.

\begin{abstract}
Abbreviation key: CNMP = comprehensive nutrient management plan, HPUE = herd phosphorus utilization efficiency, $\mathbf{M S E}=$ manure storage efficiency.
\end{abstract}

\section{INTRODUCTION}

The dairy industry has been identified as a potential contributor to environmental pollution from excess phosphorus. Phosphorus has been shown to build up in the soil of livestock farming operations (Wang et al., 1999) and contributes to surface water $P$ through runoff. Research suggests that P contributes to increased eutrophication of surface water through a process that increases algae growth and disrupts the ecosystem of the water, resulting in increased fish losses (Sharpley et al., 1994). Excess P may also cause toxic algal blooms that may be dangerous to human health (USDA, 1999). In an effort to curb these detrimental effects, the USDA and EPA have established that most animal feeding operations must develop a comprehensive nutrient management plan (CNMP; USDA, 1999). For producers to comply with new regulations, they must be able to quantify and adjust P imbalances that occur on-farm. VanDyke et al. (1999) showed that implementation of a CNMP can increase the profitability of a farm by increasing the efficiency with which it operates.

Most of the research conducted on whole-farm $\mathrm{P}$ balances has been done with either computer models (Aarts et al., 1992; Kuipers et al., 1999; Wang et al., 2000), or case studies involving one dairy (Bacon et al., 1990; Van Horn et al., 1996; Klausner et al., 1998). None have been carried out in the western United States. Studies involving actual dairy farms (Bacon et al., 1990; Klausner et al., 1998) or models (Aarts et al., 1992; Van Horn et al., 1996; Kuipers et al., 1999) suggest that 44 to $66 \%$ of the imported $\mathrm{P}$ was unaccounted for in product (difference between inputs and outputs) in their whole-farm balances. All report that purchased feeds were the primary source of input for the wholefarm $\mathrm{P}$ balance and estimates ranged from 63 to $81 \%$ of total inputs. Wang et al. (2000) utilized the Cornell Net Carbohydrate and Protein System to model alternatives for lowering whole-farm phosphorus balance. 
The primary management change that affected $\mathrm{P}$ balance was to increase the yield of crops grown on-farm that would decrease purchased feed.

Additional information on whole-farm $\mathrm{P}$ balance comes from studies that examined subsystems of the dairy farm. Manure and soil P management studies (Sharpley et al., 1994, 1996; Shepard, 2000) have shown that $\mathrm{P}$ builds up in the soil on dairy farms and may have a negative environmental effect. Proper balancing of rations and management of feed resources have shown positive effects on whole-farm $\mathrm{P}$ balances (Van Horn et al., 1994; Wang et al., 2000). Morse et al. (1992) showed that $\mathrm{P}$ excretion by lactating cows increased with increased $\mathrm{P}$ intake, also suggesting that efficient management of feed may be a significant opportunity for lowering excess $\mathrm{P}$ on-farm.

Hutson et al. (1998) reported the need for a system that would allow for construction of whole-farm nutrient balances for a large number of farms. A spreadsheet model called the Maryland Nutrient Balancer (Kohn, 2001), based on the same principles as the worksheets developed by Dou et al. (1996, 1998), was developed that accounted for whole-farm $\mathrm{N}$ and $\mathrm{P}$ balances by quantifying all forms of $\mathrm{N}$ and $\mathrm{P}$ coming onto as well as leaving the farm. Koelsch and Lesoing (1999) reported whole-farm balances for 33 beef and swine confinement livestock operations, but there have been no published studies of whole-farm $\mathrm{P}$ balance involving a large database of commercial dairy farms. There has been little work evaluating the interactions of the subsystems that make up whole-farm $\mathrm{P}$ balance.

The objectives of this study were 1) to determine whole-farm $\mathrm{P}$ balance and its components, and 2) determine the relative contributions of the herd, manure storage, and crop production components to differences in whole-farm $\mathrm{P}$ balance. The $\mathrm{N}$ balance of these same farms is the focus of a companion paper (Spears et al., 2003).

\section{MATERIALS AND METHODS}

\section{Data and Sample Collection}

Data were collected from 41 dairy farms (34 farms with Holstein and seven farms with Jersey cows as the predominant breed) selected from seven counties in Utah and six counties in Idaho. Farms were selected from counties that had at least 5000 dairy cows (Idaho Agricultural Statistics Service, 1999; Utah Agricultural Statistics Service, 1999). Within each county, producers were identified who were members of the DHI and willing to cooperate in the study. On 23 farms one or more crops were grown, while on 18 farms, all feedstuffs were purchased. Farms that grew crops bought 1.3 to $92.8 \%$ of their feed and used 5 to $100 \%$ of their manure on- farm, while farms that did not grow any crops exported all their manure.

Producers were initially contacted by phone, and then sent a letter outlining their involvement in the project. They were subsequently interviewed face-to-face to collect information needed for the Maryland Nutrient Balancer (Kohn, 2001), and the program was used to create a whole-farm $\mathrm{P}$ balance for each farm. Feed data were gathered from producer records which included actual receipts, ration sheets, and nutritional information directly obtained from their consultant. Tons of feed and fertilizer purchased was converted to tons of $\mathrm{P}$ using actual feed and fertilizer $\mathrm{P}$ analysis provided by the farmer, when available, or using National Research Council (1989) values for feed when no analysis was available. Tons of crops grown and sold were also collected from the dairy farmer and converted to tons of P. All analysis of data was done on a DM basis. Required inputs for the model were: tons of purchased feed and fertilizer, tons of crops grown and sold, number of cows purchased and sold, tons of manure exported and its $\mathrm{P}$ content, and annual milk weights sold. Production characteristics such as milk protein percent (CP), rolling herd average milk, and total cow and heifer numbers were also required inputs. An average number of animals for the whole year was used to determine the number of cows and heifers. All of the farms in the study had a supplemental source of $\mathrm{P}$ in the ration except one that did not supplement $P$.

Nutrient inputs and outputs were reported for all farms for January through December 1999 except for one farm that underwent a major change of focus in 1999. For that herd, data from June 1999 through May 2000 were reported. This farm was left in the analysis because the data included a complete year, overlapped 6 mo of the collection period for the other farms, and analysis could not detect it as an outlier. All other farms changed little during the data collection period. Farm information and manure samples were collected in the summer and fall of 2000 in order to have complete information for the 1999 year.

Five to 10 subsamples of stored manure (the number varying depending on farm size) were randomly collected from each storage facility on each farm and combined into a composite sample. Samples of manure in piles were taken from 6 to 8 inches into the pile ( 3 to 5 samples per pile) in order to obtain a representative sample. Samples were immediately frozen and stored for later analysis of $\mathrm{P}$ content. Total tons of manure coming out of storage were estimated from NRCS values (USDA-NRCS, 1992) and combined with the P content of the manure so that total tonnes of $\mathrm{P}$ coming out of storage could be compared with the amount going into storage. 
Table 1. Calculations used by the Maryland Nutrient Balancer program.

\begin{tabular}{ll}
\hline Efficiency & Calculation \\
\hline $\begin{array}{l}\text { P Inputs, kg } \\
\text { P Outputs, kg }\end{array}$ & $\begin{array}{l}\text { Imported feed P + imported bedding P + imported animals P + imported fertilizer P } \\
\text { Whole-farm P balance } \\
\text { (or actual unaccounted P), kg }\end{array}$ \\
$\begin{array}{l}\text { P in animal products + P in cash crops + exported manure and compost P } \\
\text { Terd P utilization efficiency }\end{array}$ & \\
Manure P produced, kg & Kg P in product (milk and meat)/kg P in feed \\
Manure P storage efficiency & Animal P intake - P in animal product (milk and meat) \\
Manure P available to crop, kg & Total kg manure P that is exported from farm or applied to crops/manure P produced \\
Availability of applied manure & Kg manure P applied - P field loss (was zero for these analyses) \\
Crop P utilization efficiency & Manure P available to crop/manure P applied \\
Manure P applied, kg & Total P in crop/Total P available to crop (sum of available manure and fertilizer P) \\
& Manure P stored + imported manure P (no farms imported in this study) \\
& - exported manure P \\
\hline
\end{tabular}

\section{Laboratory Procedures}

Stored manure samples were analyzed for DM by drying in a forced air oven at $60^{\circ} \mathrm{C}$, ground through a 1 -mm screen in a Wiley Mill, then further dried at $105^{\circ} \mathrm{C}$. The DM content was then determined based on final weight of the sample (AOAC, 1984). Ground samples dried at $60^{\circ} \mathrm{C}$ were analyzed for $\mathrm{P}$ by digestion according to the Zasoski and Burau (1977) procedure with predigestion of samples with $5.0 \mathrm{ml}$ of nitric acid. Inorganic phosphorous was then analyzed by inductively coupled plasma emissions spectroscopy (model Accuris; Fisons Instruments, En Vallarie, Switzerland) at $178.27 \lambda$ wavelength.

\section{Calculations Within the Maryland Nutrient Balancer}

The Maryland Nutrient Balancer (Kohn, 2001) calculated whole-farm $\mathrm{P}$ balance summaries and several efficiencies that were used in later analyses. These efficiencies and the methods used to calculate them are shown in Table 1.

\section{Statistical Analysis}

The data were analyzed as a completely randomized design with individual farm as the experimental unit. Descriptive statistics were analyzed for the complete dataset. Whole-farm $\mathrm{P}$ balance was expressed per kilogram of milk and meat $\mathrm{P}$ (balance per product) to eliminate the effect of herd size on farm balance. A univariate regression model was developed with whole-farm $\mathrm{P}$ balance per product as the dependent variable and herd phosphorus utilization efficiency (HPUE), manure P storage efficiency (MSE), imported feed per product, annual average milk production per cow, herd size, manure exported per product, imported fertilizer per product, total $\mathrm{P}$ available to crop, total $\mathrm{P}$ in the crop, availability of manure $\mathrm{P}$ applied, or uptake of available $\mathrm{P}$ as the independent variables. A multivariate model was developed to determine the relative importance of subsystem efficiencies on whole-farm $\mathrm{P}$ balance per product with HPUE, MSE, and crop P utilization efficiencies as the independent variables. Further univariate analyses with HPUE as the dependent variable and herd size, milk production, herd nitrogen utilization efficiency, and total $\mathrm{P}$ input per product as the independent variables. Breed of cow was not significant; therefore, herds from both breeds were combined in the analyses. Regression analyses were performed in SAS (1996) using Proc GLM. Differences between variables were considered to be significant at the $P<0.05$ level.

\section{RESULTS AND DISCUSSION}

\section{Description of Farms}

Herds involved in the study provided a wide range of measured variables and, therefore, a wide range in calculated efficiencies (Tables 2 and 3). Herd size ranged from 57 to 1960 cows and averaged 466 cows. Milk production ranged from 6568 to $13,863 \mathrm{~kg}$ of milk/ cow with an average of $10,344 \mathrm{~kg} / \mathrm{yr}$. Herd P utilization efficiency ranged from 0.084 to 0.589 , with an average of 0.317 suggesting that $31.7 \%$ of all $\mathrm{P}$ fed to the herd (cows and replacement heifers) was converted into either milk or meat $\mathrm{P}$ based on the law of mass conservation used by the Balancer to make this calculation. Close to half of the farms in this study (44\%) imported all feed.

Farms were further divided into those that grew any crops (Table 2) and those that grew no crops (Table 3). Farms that grew crops averaged 284 cows with a range of 57 to 1450 cows. Milk production averaged $9732 \mathrm{~kg} /$ cow per year with a range of 3402 to $12,659 \mathrm{~kg} / \mathrm{cow}$ per year. Average HPUE was $30.2 \%$, MSE was $95.6 \%$, and crop P utilization was $66.6 \%$. For farms that grew no crops, average herd size was 700 cows with a range of 62 to 1960 . Milk production averaged 10,922 kg/cow 
Table 2. Summary of selected variables for farms that grew any crops $(n=23)$.

\begin{tabular}{lcccc}
\hline Parameter & Mean & SD & Minimum & Maximum \\
\hline Total herd size of cows & 284 & 297 & 57 & 1450 \\
Herd size of heifers & 242 & 233 & 35 & 1125 \\
Milk production, kg per cow $^{\text {Milk protein, \% }}$ & 9732 & 2405 & 3402 & 12,659 \\
Herd P utilization efficiency $^{1}$ & 3.33 & 0.293 & 2.90 & 4.02 \\
Manure P storage efficiency $^{2}$ & 0.302 & 0.103 & 0.084 & 0.589 \\
Crop P utilization efficiency $^{3}$ & 0.956 & 0.426 & 0.241 & 1.87 \\
\hline
\end{tabular}

${ }^{1} \mathrm{Kg} \mathrm{P}$ in product (milk and meat)/kg of $\mathrm{P}$ in feed.

${ }^{2}$ Total amount of manure $\mathrm{P}$ that is exported from farm or applied to crops/P in excreted manure (calculated by mass balance equation that is $\mathrm{P}$ in feed $-\mathrm{P}$ in product).

${ }^{3}$ Total $\mathrm{P}$ in crop/total $\mathrm{P}$ available to crop (sum of available manure and fertilizer N).

per year with a range of 6568 to $13,864 \mathrm{~kg} / \mathrm{cow}$ per year. Average HPUE was $33.7 \%$, MSE was $70.7 \%$, and crop $\mathrm{P}$ utilization efficiency was 0.0 (no crops were grown). Farms that grew no crops had 3.5\% higher HPUE and $25 \%$ lower MSE than farms that grew crops. This is a significantly lower MSE than either farms that grew crops or a theoretical efficiency of $100 \%$. This reflects either a major difference in the way manure is stored and handled on farms that grew no crops or is the result of an unknown sampling problem that has a larger impact on farms that grew crops.

\section{Whole-Farm P Balance}

Average whole-farm $\mathrm{P}$ balance, expressed as tonne of $\mathrm{P}$ per year, is shown in Table 4 . The average wholefarm $\mathrm{P}$ balance for all farms was 6.6 tonne/year per farm, indicating that more $\mathrm{P}$ was coming onto the study farms than was being accounted for in the sale of product (mostly milk), exported crops and exported manure. Imported feed accounted for $85.4 \%$ of all inputs, while the primary outputs were milk, meat, manure and compost. Previously reported whole-farm $\mathrm{P}$ efficiencies $(\mathrm{P}$ in total outputs divided by $\mathrm{P}$ in total inputs $\times 100)$ ranged from 44 (Bacon et al., 1990) to 66\% (Aarts et al., 1992). The average herd in this study
(466 cows) had a whole-farm P utilization efficiency of $62.6 \%$. This means that $37.4 \%$ of all $\mathrm{P}$ that came onto the farm could not be accounted for in animal product, cash crops, or manure and compost. Care should be taken in making comparisons between this study and values from the literature because not all farms use the same categories for inputs and outputs or had the same herd size. For example, Aarts et al. (1992) only listed milk and meat as outputs in their whole-farm balance. In this study of dairies in the western United States, six farms (14.6\%) showed a whole-farm net loss of $\mathrm{P}$.

Average whole-farm $\mathrm{P}$ balance, in tonne of $\mathrm{P}$ per year, was further subdivided and evaluated for farms that grew crops and farms that did not (Table 5). The average unaccounted for $\mathrm{P}$, on a whole-farm basis, was not different between the two groups of farms; however, this was misleading because of the differences in herd size between the two groups. When expressed on a per animal basis, farms that grew crops had more unaccounted for $\mathrm{P}$. This can be seen in the ratio of $\mathrm{P}$ in output compared with input that shows that farms that grew crops accounted for over $30 \%$ less $\mathrm{P}$ that came onto the farm than farms that grew no crops. A major difference between the two groupings was that farms that grew crops imported fertilizer for crops and had

Table 3. Summary of selected variables for farms that grew no crops $(n=18)$.

\begin{tabular}{lcccc}
\hline Parameter & Mean & SD & Minimum & Maximum \\
\hline Total herd size of cows & 700 & 586 & 62 & 1960 \\
Herd size of heifers $_{\text {Milk production, kg per cow }}^{404}$ & 10,922 & 396 & 0 & 1400 \\
Milk protein, \% $^{\text {Herd P utilization efficiency }}{ }^{2}$ & 3.27 & 2047 & 6568 & 13,864 \\
Manure P storage efficiency $^{3}$ & 0.337 & 0.295 & 2.90 & 3.85 \\
Crop P utilization efficiency $^{3}$ & 0.707 & 0.065 & 0.232 & 0.475 \\
\hline
\end{tabular}

\footnotetext{
${ }^{1} \mathrm{Kg} \mathrm{P}$ in product (milk and meat)/kg of $\mathrm{P}$ in feed.

${ }^{2}$ Total amount of manure $\mathrm{P}$ that is exported from farm or applied to crops/P in excreted manure (calculated by mass balance equation that is $\mathrm{P}$ in feed $-\mathrm{P}$ in product).

${ }^{3}$ Total $\mathrm{P}$ in crop/total $\mathrm{P}$ available to crop (sum of available manure and fertilizer $\mathrm{N}$ ).
} 
Table 4. Average whole-farm $\mathrm{P}$ balance per farm (tonnes of $\mathrm{P}$ per year) as calculated by the Maryland Nutrient Balancer. Average herd size was 466 cows and milk production was 10,344 kg per cow per year. Phosphorus balance is the difference between $\mathrm{P}$ inputs and outputs.

\begin{tabular}{lcccc}
\hline Variable & Average & SD & Minimum & Maximum \\
\hline P inputs & 17.8 & 17.8 & 1.6 & 67.9 \\
Imported feed & 15.2 & 16.7 & 0.4 & 64.9 \\
Imported bedding & 0.3 & 0.5 & 0.0 & 2.7 \\
Imported animals & 0.3 & 0.6 & 0.0 & 2.5 \\
Imported fertilizer & 2.0 & 5.8 & 0.0 & 36.7 \\
P outputs & 11.1 & 15.8 & 0.7 & 78.2 \\
Animal products & 5.9 & 6.4 & 0.6 & 24.9 \\
Cash crops & 0.1 & 0.4 & 0.0 & 60.3 \\
Manure/compost & 5.1 & 11.0 & 0.0 & 34.4 \\
P balance (potential loss) & 6.6 & 8.5 & -17.2 & \\
Output/Input, \% & 62.6 & & & \\
P balance per animal $^{1}, \mathrm{~kg} / \mathrm{yr}$ & 10.7 & & & \\
\hline
\end{tabular}

${ }^{1}$ Animals include cows plus half the number of heifers (i.e., 2 heifers $=1$ cow).

less exported manure per animal compared with farms that grew no crops. On a whole-farm basis, farms that grew no crops had 7.1 tonne/yr of $\mathrm{P}$ that could not be accounted for. This represents a large amount of $P$ that is not leaving the farm and is probably leading to a significant build-up of $\mathrm{P}$. This is in addition to a larger portion of the manure that is leaving the farm compared with farms that grew crops.

\section{Effect of Subsystems on Whole-Farm P Balance per Product}

A multiple regression analysis was used to determine the relative importance of the subsystems (herd, manure, and crop management) on whole-farm balance per product. The multiple regression model for those farms that grew crops is shown in Table 6. The model accounted for $72 \%$ of the variation in whole-farm $\mathrm{P}$ balance per product. Herd phosphorus utilization effi- ciency explained $82.7 \%$ of the model variation and crop uptake of available $\mathrm{P}$ explained $17.3 \%$. Manure storage efficiency and availability of applied manure were not significant in the model. However, even though MSE and availability of manure $\mathrm{P}$ were not significant in the model, they should still be considered important methods for reducing whole-farm $\mathrm{P}$ balance/product (Table 7).

The significant relationship between whole-farm $\mathrm{P}$ balance per product and HPUE is consistent with other research reports. Wang et al. (2000), using measured values from their base farm, estimated that by feeding lactating cows based on production level, rather than as a single group, whole-farm $\mathrm{P}$ balance could be decreased by $9 \%$. On an average farm, cows receive excess dietary $\mathrm{P}$ (Wu et al., 2001) that will be excreted almost on a 1:1 basis as excess $\mathrm{P}$ (Morse et al., 1992). Those animals would have a lower HPUE because the excess $\mathrm{P}$ in the feed is not being converted into product (milk

Table 5. Average of whole-farm $\mathrm{P}$ balance per farm, expressed as tonne $\mathrm{P} / \mathrm{year}$ or $\mathrm{kg} / \mathrm{animal}$, as calculated by the Maryland Nutrient Balancer for those farms that grew crops and those farms that grew no crops. Phosphorus balance is the difference between inputs and outputs.

\begin{tabular}{|c|c|c|c|c|c|c|}
\hline \multirow[b]{2}{*}{ Variable } & \multicolumn{3}{|c|}{ Grew crops } & \multicolumn{3}{|c|}{ Grew no crops } \\
\hline & $\begin{array}{l}\text { Mean, } \\
\text { T/yr }\end{array}$ & SD & $\begin{array}{l}\text { kg per } \\
\text { animal }^{1}\end{array}$ & $\begin{array}{l}\text { Mean, } \\
\text { T/yr }\end{array}$ & SD & $\begin{array}{l}\text { kg per } \\
\text { animal }^{1}\end{array}$ \\
\hline Phosphorus inputs & 11.0 & 11.5 & 26.6 & 26.5 & 20.8 & 29.4 \\
\hline Imported feed & 7.2 & 6.4 & 17.4 & 25.6 & 20.0 & 28.4 \\
\hline Imported bedding & 0.2 & 0.2 & 0.4 & 0.4 & 0.6 & 0.4 \\
\hline Imported animals & 0.1 & 0.1 & 0.2 & 0.5 & 0.8 & 0.5 \\
\hline Imported fertilizer & 3.6 & 7.4 & 8.7 & 0.0 & 0.0 & 0.0 \\
\hline Phosphorus outputs & 4.6 & 4.9 & 11.2 & 19.4 & 20.7 & 21.5 \\
\hline Animal products & 3.6 & 4.2 & 8.8 & 8.8 & 7.6 & 9.8 \\
\hline Cash crops & 0.2 & 0.5 & 0.5 & 0.0 & 0.0 & 0.0 \\
\hline Manure/compost & 0.8 & 1.9 & 2.0 & 10.6 & 15.0 & 11.8 \\
\hline P balance (potential loss) & 6.3 & 7.3 & 15.3 & 7.1 & 10.0 & 7.8 \\
\hline Output/input, \% & 42.3 & & & 73.4 & & \\
\hline
\end{tabular}

\footnotetext{
${ }^{1}$ Animals include cows plus half the number of heifers (i.e., 2 heifers $=1 \mathrm{cow}$ ).
} 
Table 6. Results of multiple regression analysis of whole-farm P balance, expressed on a per product (kg milk and meat) basis, for farms that grew any crops $\left(\mathrm{R}^{2}=0.56\right)$.

\begin{tabular}{lccrr}
\hline Factor & Estimate & SE & $\%$ SS & $P$-value \\
\hline Intercept & 7.36 & 0.862 & & $<0.0001$ \\
Herd phosphorus utilization efficiency (HPUE) & -16.42 & 2.731 & 64.0 & $<0.0001$ \\
Crop uptake of available P & -1.11 & 0.355 & 17.3 & 0.0056 \\
HPUE * HPUE & 49.16 & 15.127 & 18.7 & 0.0042 \\
\hline
\end{tabular}

and meat). In addition, Van Horn et al. (1996) suggested that ruminants might be more efficient than previously thought in utilizing dietary $\mathrm{P}$ because of their ability to recycle $\mathrm{P}$ through saliva. Results from this study support the concept that increased efficiency of $\mathrm{P}$ conversion from feed to milk and meat is an important method for decreasing whole-farm $\mathrm{P}$ balance per product for farms that grew crops.

For farms that grew crops, total P available for crops, primarily as manure $P$, was significantly related to increased whole-farm $\mathrm{P}$ balance per product (Table 7), while imported fertilizer per product was not significant. Although we cannot determine causality from our dataset, this may be a reflection of producers not crediting manure $\mathrm{P}$ content applied to crops, thereby overapplying manure $\mathrm{P}$ relative to the needs of the crop. Crop selection to maximize $\mathrm{P}$ uptake would also be important.

By increasing manure $\mathrm{P}$ uptake by crops or more precisely matching manure $\mathrm{P}$ application to crop needs, more $\mathrm{P}$ can be recycled through crops lowering wholefarm $\mathrm{P}$ balance. This could decrease the amount of imported fertilizer and lead to lower operating costs as well as decreased P inputs. Shepherd (2000) reported that fewer than $2 \%$ of farmers credited manure nutrient content accurately and most did not credit manure nutrient content at all. VanDyke et al. (1999) found that by properly crediting manure nutrient content, wholefarm P balance was reduced. Klausner et al. (1998) found that enough nutrients were contained in manure for the needs of the crops, but noted the difficulty in applying manure at the correct time and in the correct method so that nutrients were available to the crops.

It is possible that uptake of manure $\mathrm{P}$ was influenced by the amount of $\mathrm{P}$ already in the soil. Because the

Table 7. Univariate regression equations of selected variables to whole-farm phosphorus balance ${ }^{1}$, expressed on a per animal product (kg milk and meat) basis, for farms that grew any crops $(\mathrm{n}=23)$.

\begin{tabular}{lcrll}
\hline Independent variable & Intercept & Slope & $\mathrm{R}^{2}$ & $P$-value \\
\hline Total P available to crops & -0.28 & 3.75 & 0.43 & 0.0006 \\
Manure P available to crops & -0.45 & 6.09 & 0.47 & 0.0003 \\
Imported fertilizer P & 1.50 & 0.63 & 0.12 & 0.108 \\
Uptake of available P & 2.96 & -1.18 & 0.17 & 0.050 \\
\hline
\end{tabular}

${ }^{1}$ Whole-farm $\mathrm{P}$ balance $=\mathrm{P}$ inputs $-\mathrm{P}$ outputs . model used for this study was intended only to calculate actual inputs and outputs for one year, $\mathrm{P}$ accumulation in the soil from previous years was not measured. Wang et al. (2000) found that crop uptake of available P influenced whole-farm $P$ balance suggesting that increasing the proportion of cropland used to grow particular crops that use more $\mathrm{P}$, compared to a crop that uses less $\mathrm{P}$, would improve whole-farm $\mathrm{P}$ balance.

Multiple regression analysis of farm subsystems for those farms that grew no crops found that only MSE was significantly $\left(R^{2}=0.729\right.$, negative slope) related to whole-farm $\mathrm{P}$ balance per product. This overemphasis on MSE may be misleading because most of the manure on these farms is exported making MSE seem more important than HPUE when only a fraction of the subsystem leaves the farm. Exporting all manure off-farm could be an effective way to balance a farm's CNMP, but from a watershed perspective, it may be a problem. Even though HPUE was not significant with wholefarm $\mathrm{P}$ balance per product for farms that grew no crops, increasing feed $\mathrm{P}$ conversion to product may present an opportunity to increase the amount of $\mathrm{P}$ exported in product and reduce the total amount of $\mathrm{P}$ exported as manure or compost.

The calculation for determining the amount of manure $\mathrm{P}$ produced used by the Maryland Nutrient Balancer is $\mathrm{P}$ in feed minus $\mathrm{P}$ in product, based on the law of mass conservation (Table 1; Van Horn, 1994). All P that is not accounted for in the form of animal products (milk or meat) is assumed to be in the manure. The manure $\mathrm{P}$ level leaving the storage system, whether applied to crops or exported off-farm, was determined from samples collected at each individual farm. It is possible that some of the variations between farms are due to sampling problems; however, it is just as likely that some of the variation may be due to the mixtures of manure and bedding, storage type (piles, compost, lagoons), weather, length of time in storage, percentage of storage facility that is actually emptied, etc. These variations would be found in applied situations and may be important considerations for those collecting information for whole-farm balances. In addition, several farms in this study had MSE greater than 1.0, which caused a negative whole-farm $\mathrm{P}$ balance per product. This means that more $\mathrm{P}$ was in the manure as it 
Table 8. Univariate regression associations between herd $\mathrm{P}$ utilization efficiency ${ }^{1}$ and selected variables for farms that grew any crops $(\mathrm{n}=23)$ and farms that grew no crops $(\mathrm{n}=18)$.

\begin{tabular}{llclcc}
\hline & \multicolumn{2}{c}{ Grew crops } & & \multicolumn{2}{c}{ Grew no crops } \\
\cline { 2 - 3 } Independent variable & $\mathrm{R}^{2}$ & $P$-value & & $\mathrm{R}^{2}$ & $P$-value \\
\hline P input per product, $\mathrm{kg} / \mathrm{kg}$ & $0.454^{3}$ & 0.0004 & $0.941^{3}$ & $<0.0001$ \\
Milk yield, kg/yr & 0.060 & 0.248 & 0.270 & 0.027 \\
Herd N utilization efficiency, $\mathrm{kg} / \mathrm{kg}^{2}$ & 0.539 & $<0.0001$ & 0.186 & 0.074 \\
Herd size & 0.127 & 0.095 & & 0.071 & 0.284 \\
\hline${ }^{1}$ Herd P utilization efficiency = P in product (milk and meat)/P in feed. & & \\
${ }^{2}$ Herd N utilization efficiency = N in product (milk and meat)/N in feed (Spears and Young, 2002). \\
${ }^{3}$ Denotes negative slope in model.
\end{tabular}

was removed from storage compared with the amount of $\mathrm{P}$ predicted to be in manure based on the law of mass conservation. Almost all of the dairies with efficiencies greater than 1.0 housed their cows in open dry lots compared with free stalls. Manure from dry lots was collected by scraping the top surface of the lot. Phosphorus build-up on the top layer of soil may get incorporated with the manure and could increase the apparent amount of $\mathrm{P}$ in stored manure. This is an area where further work is needed.

\section{Herd P Utilization Efficiency}

As HPUE was a significant factor in explaining whole-farm $\mathrm{P}$ balance per product, further univariate analysis of factors affecting HPUE were evaluated (Table 8 ). Whole-farm herd $\mathrm{P}$ input per product was negatively related to HPUE for both farms that grew crops and those that did not. The negative relationship of HPUE with whole-farm $\mathrm{P}$ input per product suggests that lowering the amount of purchased feed or P supplement would increase the efficiency of $P$ utilization because feed $\mathrm{P}$ is the largest single source of $\mathrm{P}$ coming onto the farm.

Higher milk yields were associated with increased conversion of feed $\mathrm{P}$ to product $\mathrm{P}$ (Table 8) for farms that grew no crops, but not for farms that grew crops. For farms that grew no crops this was important because increased exportation of $\mathrm{P}$ in product or $\mathrm{P}$ in manure and compost are almost the only ways they can improve whole-farm $\mathrm{P}$ balance per product. Wang et al. (2000) estimated that increasing whole-farm milk yield by $10 \%$ per cow decreased whole-farm N, P, and K balance better than increasing cow numbers to reach a $10 \%$ increase in total farm milk yield compared with measured values from a base herd.

Herd N utilization efficiency (Spears et al., 2003) was related positively to HPUE for farms that grew crops and showed a trend for farms that grew no crops $(P=$ 0.07 ), suggesting that managing for increased efficiency of one nutrient was associated with increased efficiency of utilization of the other. Although our data does not allow us to determine the reasons these two variables were related, two possibilities are suggested. The first may be related to the composition of milk. Wu et al. (2001) reported a positive relationship between milk P concentration and milk protein concentration. It was suggested that because phosphate bridges hold casein micelles in milk together, increased milk protein would require an increase in milk phosphorus even though this form of $\mathrm{P}$ comprises only a small fraction of the total milk $\mathrm{P}$. The second possibility may be that rations properly balanced for $\mathrm{P}$ are also being balanced for protein. It is interesting to note that in a study where adjustments were made to lower whole-farm $\mathrm{N}$ balance, whole-farm P balance was also decreased (Bacon et al., 1990).

Herd size was not associated with HPUE (Table 8). This is interesting because larger farms often have more flexibility in grouping animals according to production and should be more efficient in converting feed $\mathrm{P}$ to $\mathrm{P}$ in milk and meat. Even though the larger herds in this study did group their cows more than the smaller herds, they were not associated with greater efficiency. Wang et al. (2000) reported an estimated decrease in farm $P$ mass balance when cows were divided into three groups according to production level rather than feeding one ration formulated for the high producing animals. Whole-herd $\mathrm{P}$ balance per product and HPUE were not associated with either the number of heifers per herd or the ratio of heifers to cows for farms that did or did not grow crops.

\section{CONCLUSIONS}

The average whole-farm $\mathrm{P}$ balance, on a tonne per year basis was 6.6 tonne over 41 farms with an average herd size of 466 cows. Farms that grew crops accounted for less of the $\mathrm{P}$ that came onto the farm than those that did not grow crops. When corrected for herd size, farms that grew crops had a twofold greater P balance than farms that grew no crops. Farms that grew no 
crops had almost all inputs as feed, no imported fertilizer, and more manure and compost as outputs than farms that grew crops. Increasing conversion of feed $P$ to $\mathrm{P}$ in product is an important way to help reduce whole-farm P balance. The farm components that had the greatest impact on whole-farm $\mathrm{P}$ balance per product for farms that grew crops, and thereby the greatest potential for improvement, were HPUE and crop uptake of available $\mathrm{P}$.

\section{REFERENCES}

AOAC. 1984. Official Methods of Analysis. 14th ed. Association of Official Analytical Chemists, Washington, DC.

Aarts, H. F. M., E. E. Biewinga, and H. Van Keulen. 1992. Dairy farming systems based on efficient nutrient management. Neth. K. Agric. Sci. 40:285-299.

Bacon, S. C., L. E. Lanyon, and R. M. Schlauder, Jr. 1990. Plant nutrient flow in the managed pathways of an intensive dairy farm. Agron. J. 82:755-761.

Dou, Z., R. A. Kohn, J. D. Ferguson, R. C. Boston, and J. D. Newbold. 1996. Managing nitrogen on dairy farms: An integrated approach. I. Model description. J. Dairy Sci. 79:2071-2080.

Dou, Z., L. E. Lanyon, J. D. Ferguson, R. A. Kohn, R. C. Boston, and W. Chalupa. 1998. An integrated approach to managing nitrogen on dairy farms: evaluation of farm performance using the Dairy Nitrogen Planner. Agron. J. 90:573-581.

Hutson, J. L., R. E., Pitt, R. K. Koelsch, J. B. Houser, and R. J. Wagenet. 1998. Improving dairy farm sustainability II: Environmental losses and nutrient flows. J. Prod. Agric. 11:233-239.

Idaho Agricultural Statistics Service. 1999. Idaho county estimates. June 16. Online. Available: http://nass.usda.gov/id.

Klausner, S. D., D. G. Fox, C. N. Rasmussen, R. E. Pitt, T. P. Tyluntki, P. E., Wright, L. E. Chase, and W. C. Stone. 1998. Improving dairy farm sustainability I: An approach to animal and crop nutrient management planning. J. Prod. Agric. 11:225-223.

Koelsch R., and G. Lesoing. 1999. Nutrient balance on Nebraska livestock confinement systems. J. Dairy Sci. 82(Suppl. 2):63-71.

Kohn, R. A. Maryland Nutrient Balancer. 2001. Online. Available: http://www.umd.edu/ManureNet/Software.

Kuipers, A., F. Mandersloot, and R. L. G. Zom. 1999. An approach to nutrient management on dairy farm. J. Dairy Sci. 82(Suppl. 2):84-89.

Morse, D., H. H. Head, C. J. Wilcox, H. H. Van Horn, C. D. Hissem, and B. Harris, Jr. 1992. Effects of concentration of dietary phosphorus on amount and route of excretion. J. Dairy Sci. 75:3039-3049.
National Research Council. 1989. Nutrient Requirements of Dairy Cattle. 6th rev. ed. Natl. Acad. Sci., Washington, DC.

SAS. 1996. SAS/STAT User's Guide: (Release 6.12). SAS Inst. Inc., Cary, NC.

Sharpley, A., S. C. Chapra, R. Wedepohl, J. T. Sims, T. C. Daniel, and K. R. Reddy. 1994. Managing agricultural phosphorus for protection of surface waters: Issues and options. J. Environ. Qual. 23:437-451.

Sharpley, A., T. C. Daniel, J. T. Sims, and D. H. Pote. 1996. Determining environmentally sound soil phosphorus levels. J. Soil Water Cons. 51:160-166.

Shepherd, R. 2000. Nitrogen and phosphorus management on Wisconsin farms: Lessons learned for agricultural water quality programs. J. Soil Water Cons. 55:63-68.

Spears, R. A., R. A. Kohn, and A. J. Young. 2003. Whole-farm nitrogen balance on western dairy farms. J. Dairy Sci. (In press).

U. S. Department of Agriculture-NRCS. 1992. Agricultural waste characteristics. Part 651 in Agricultural Waste Management Field Handbook.

U. S. Department of Agriculture. U. S. Environmental Protection Agency. 1999. Unified national strategy for animal feeding operations. Online. Available: http://www.epa.gov/owm/finafost.

Utah Agricultural Statistics Service. 1999. Annual Bulletin Pages. Cattle, Utah January 1998 (revised) and 1999. Online. Available: http://www.nass.usda.gov/ut/Pdf/ab99/99107.pdf.

VanDyke, L. S., J. W. Pease, D. J. Bosch, and J. C. Baker. 1999. Nutrient management planning on four Virginia livestock farms: Impacts on net income and nutrient losses. J. Soil and Water Conserv. 51:499-505.

Van Horn, H. H., G. L. Newton, and W. E. Kunkle. 1996. Ruminant nutrition from an environmental perspective: Factors affecting whole-farm nutrient balance. J. Anim. Sci. 74:3082-3102.

Van Horn, H. H., A. C. Wilkie, W. J. Powers, and R. A. Nordstedt. 1994. Components of dairy manure management systems. J. Dairy Sci. 77:2008-2030.

Wang, S. J., S. G. Fox, D. J. R. Cherney, L. E. Chase, and L. O. Tedeschi. 2000. Whole-herd optimization with the Cornell Net Carbohydrate and Protein System. III. Application of an optimization model to evaluate alternatives to reduce nitrogen and phosphorus mass balance. J. Dairy Sci. 83:2160-2169.

Wang, S. J., S. G. Fox, D. J. R. Cherney, S. D. Klausner, and D. R. Bouldin. 1999. Impact of dairy farming on well water nitrate level and soil content of phosphorus and potassium. J. Dairy Sci. 82:2164-2169.

Wu, Z., L. D. Satter, A. J. Blohowlak, R. H. Stauffacher, and J. H. Wilson. 2001. Milk production, estimated phosphorus excretion, and bone characteristics of dairy cows fed different amounts of phosphorus for two or three years. J. Dairy Sci. 84:1738-1748.

Zasoski, R. J., and R. G. Burau. 1977. A rapid nitric perchloric acid digestion method of multielement tissue analysis. Comm. Soil Sci. Plant Anal. 3:425-436. 